\title{
The Role of Comprehensive Information Sharing in Credit Market: Theoretical Analysis and New Evidence from the European Union
}

\author{
Naihong Hu, Wenchen Gu \\ Shanghai University of Finance and Economics, Shanghai, China \\ Yuze Zhou \\ Peking University, Beijing, China
}

\begin{abstract}
This paper investigates the effect of the comprehensive information sharing on aggregate credit volume and the default ratio. Firstly, we utilize a three-stage game model developed by Dell'Ariccia and Marquez (2006) to illustrate that the comprehensive information sharing would change the credit resource allocation and produce negative "composition effects" stated by Jappelli and Pagano (2005). Then we use European Union (EU) data to test these theoretical implications. We find that when the information sharing system develops to a relatively high level, comprehensive information sharing improvements, for both the width and depth, are associated with the rise in macro credit access but also the aggregate default risk. We further find that the macro-consequences of variations in information sharing just differ in OECD and non-OECD group in EU countries. For OECD countries, the negative "composition effects" mainly arise from the increase in the width of information sharing while these effects are correlated with both the rise in depth and width indicators for non-OECD countries.
\end{abstract}

Keywords: information sharing, credit access, credit default risk

\section{Introduction}

In recent years, the trend of the comprehensive information sharing development, which is acknowledged as imperatives for safe and responsible financial systems, has been prevailing in many countries. The comprehensive information sharing can be specifically explained through the vertical and horizontal aspects: The vertical aspect of comprehensive information sharing refers that the information sharing system covers the population and firms on large scales (usually more than 90\%). The horizontal aspect of comprehensive information sharing means that credit bureaus can collect data from multiple sectors (banking, retailing, official and even online agencies) and report information of both negative types (delinquencies, defaults, bankruptcy and liens) and positive types (on-time payments, credit utilizations, balance account, etc.). The comprehensive information sharing system contrasts sharply to the "limited" ones in which sharing mechanism is restricted to certain type of borrowers (usually large borrowers) and the content of information can be described as "thin" (only negative or incomplete information within one sector).

Naihong Hu, Associate Professor, the School of Finance, Shanghai University of Finance and Economics. Email: naihong@mail.shufe.edu.cn.

Wenchen Gu, Ph.D., the School of Finance, Shanghai University of Finance and Economics.

Yuze Zhou, B.S., the School of Mathematical Sciences, Peking University. 
Previously, an extensive literature has investigated the role of information sharing in credit market. However, less attention has been paid to institutional arrangement (such as the specific scope and depth) that the information sharing system should develop. Put it differently, whether the comprehensive information sharing system, which provides full-file report and covers the whole population is the most economically-efficient still deserves further investigations. For developing countries such as China and India with huge population, establishing the comprehensive information sharing system means onerous social cost. Therefore, it is particularly important to examine whether the comprehensive information sharing system outweighs the limited ones.

To address these issues, we start with a model originally developed by Dell'Ariccia and Marquez (2006). In their paper, Dell'Ariccia and Marquez (2006) presented a model to examine how the bank's strategic behaviors for lending interact with the reductions in information asymmetry in credit market. Based on their model, we further add the width and depth parameters of information sharing. We use the parameter "proportion of borrowers whose information has been shared" to simplify the width indicator and the type of information shared for "negative only" or "both negative and positive" to simplify the depth indicator. The model reveals that when the proportion of borrowers whose information shared exceeds a certain level, banks will change their lending strategies from "screening" to "pooling", which increase credit access and default risk. Additionally, when the percentage of borrowers whose information shared is high (width indicator), change in the type of information shared from "negative" to "both positive and negative" information shared (depth indicator) can directly lead to a conversion of credit allocation equilibrium from "screening" to "pooling", lowering the loan performance as mentioned.

Then we use the data set on European Union (EU) countries from 2004 to 2014 to examine the real impacts of information sharing system development on credit market. Section 4.4 for sample description clearly shows that those EU countries had developed relatively mature information sharing system (both width and depth) in 2004 and manifested the trend of comprehensive information sharing since then. The empirical results in Section 5 indicate that at the mature stage, further improvements in scope and depth of information sharing system are associated with higher credit access and default risk, which corresponds to the predictions of our theoretical model. Considering the economic and information sharing system development differences in some transition countries of EU, we further divided the sample into OECD and non-OECD groups and compared the impacts of the information sharing system developments on the two types of economies. Regressions reveal that increases in the aggregate credit access and default risk for these two groups derive from different aspects of information sharing.

In credit market, information sharing occurs either through the "Private Credit bureau" or through the "Public Credit register". Restricted by the accessibility of data, studies on the influences of information sharing mainly went through three stages. Early literatures in the 1990s primarily focused on the theoretical analysis. Theories at this stage suggested that information sharing is substantially relevant to overcome adverse selection and moral hazard arising from information asymmetry in credit market. This progress is mainly achieved through several aspects: (1) ameliorating the quality of the pool of borrowers to reduce adverse selection

\footnotetext{
${ }^{1}$ Negative information: Adverse payment information on a borrower, which consists of late payment histories, liens, collections and bankruptcies. Positive information: Information on the timeliness of payment relative to their due date. It can also include data on account types, amount of outstanding debt, account balance as well as credit information from retail, public agency and online activities.
} 
(Pagano \& Jappelli, 1993); (2) depriving the bank's ability of extracting "information rents" to lower moral hazard (Padilla \& Pagano, 1997); and (3) exerting "discipline constraint" on individual borrower to create incentives for repayments (Padilla \& Pagano, 2000; Vercammen, 1995).

In early years of the 21 st century, surveys from the World Bank and other institutions facilitated the empirical analysis of information sharing. These studies concentrated on the macro level and delivered evidence on different countries. Opinions from Jappelli and Pagano (2002), Djankov, McLiesh, and Shleifer (2007), and Nana (2014) have reached a consensus that information sharing will promote the bank to expand the aggregate credit and improve the overall credit access. Still, there remain wide discrepancies about the role of information sharing in reducing the aggregate credit risk level. Jappelli and Pagano (2002), Houston, C. Lin, P. Lin, and Ma (2010), and Büyükkarabacak and Valev (2012) highlighted that information sharing reduces one country's credit risk and probabilities of bank crisis. However, there still exists controversy on this point of view. Dell'Ariccia and Marquez (2006) showed that under the comprehensive information sharing, information asymmetry faced by the bank will be reduced by a great amount, then banks will loosen their lending standards and increase loan supply. In the equilibrium of their model, loan portfolio performance and profits of the bank will decrease while the credit availability will increase. Brown, Jappelli, and Pagano (2009) and Jappelli and Pagano (2005) argued that through information sharing, bank can acquire the information of high risk borrowers, who would then get the loan at higher interest rate rather being refused. The greater credit access of risker borrowers will induce negative "composition effects" once the disproportional entry of higher risk borrowers overweighs the lower ones.

Supported by the data provided by credit bureaus and commercial banks, recent researches have turned to the micro level and individual behaviors. For example, Dierkes, Erner, Langer, and Norden (2013) used the data from Credit Bureau Credit Reform in Germany and demonstrated that credit information sharing has improved the accuracy of prediction and reduced the actual default rate for individual borrower. Evidence from Doblas-Madrid and Minetti (2013) who use the data provided by Paynet has showed the similar results. Additionally, the loan performance of commercial banks in some developing countries has manifested obvious improvements through the introduction of a credit registry or a credit bureau (Behr \& Sonnekalb, 2012; Fosu, 2014).

After the review of previous literatures, we find that the total effects of information sharing on the aggregate default risk are ambiguous. As reflected by Figure 1, there still exist contradictions between the cross-country evidence by Jappelli and Pagano (2002), Houston et al. (2010), and Büyükkarabacak and Valev (2012) and theoretical predictions by Brown et al. (2009) and Jappelli and Pagano (2005). A potential explanation is that most researchers only compare the differences between countries which have established information sharing system and those which have not, while ignoring the development stages of the system. The 2015 report "Implications of Siloed and Segmented Data in Credit Market" from the Policy and Economic Research Council (PERC) in North Carolina has classified the development of credit bureau into seven stages and highlights that different stages will exert different impacts on financial market. Additionally, our theoretical results in Section 2 show that with the value of width parameter of information sharing staying high, further increase in width and improvement in depth parameter will convert the equilibrium of credit allocation, resulting in the entrance of bad borrowers to banks' loan portfolio. Therefore, in this paper, we make a hypothesis that when the information sharing system develops into a relevant high level, further improvements in the width and depth of the system will produce the negative "composition effects" referred by Brown et al. (2009) and Jappelli and Pagano (2005), which increase the credit risk in the aggregate level. 

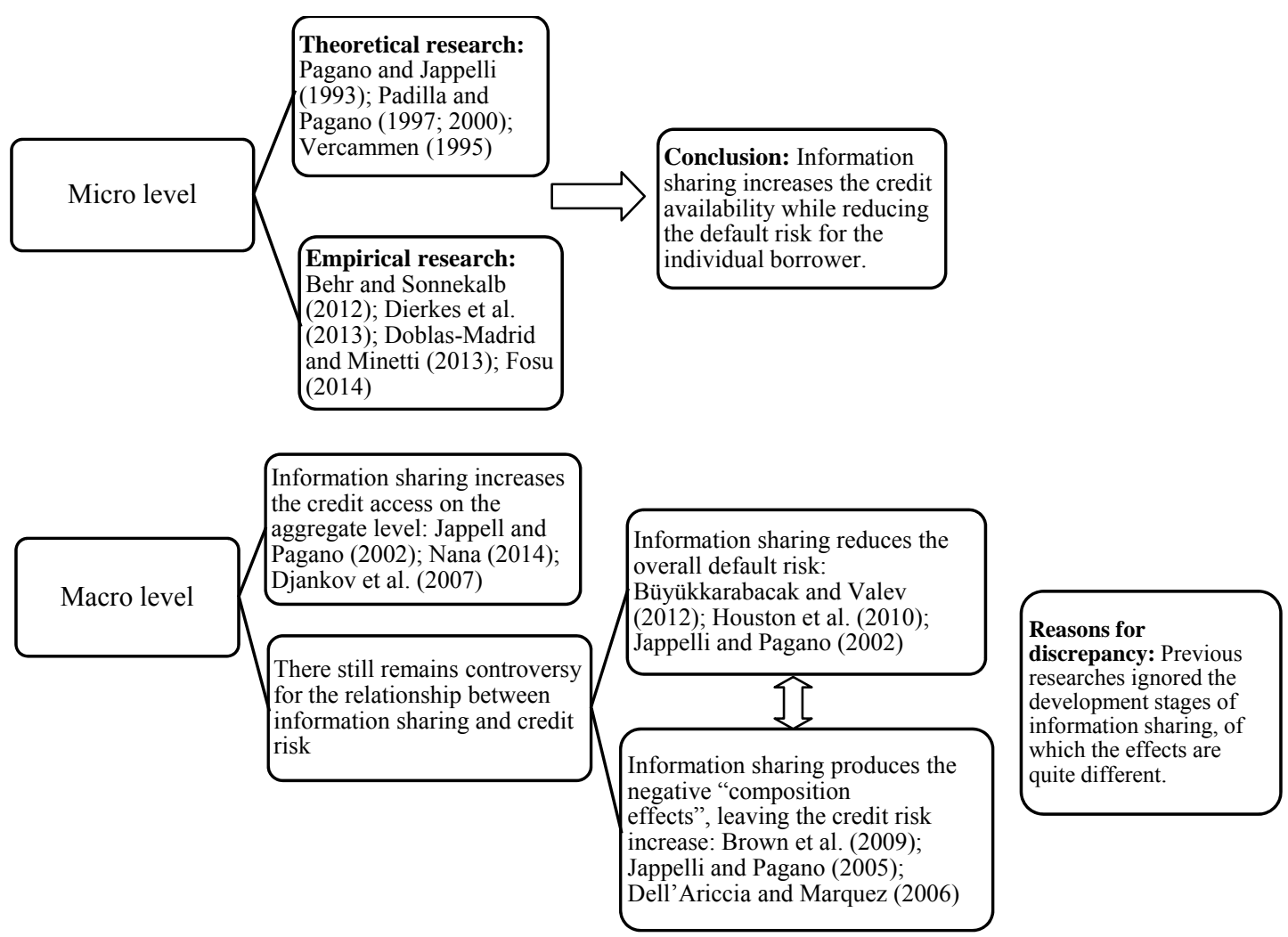

Figure 1. Previous researches about information sharing.

Additionally, unlike previous researches which measure the information sharing through a single respect, we divide the indicators of information sharing system into two aspects: the width indicator and the depth indicator. The width indicator (horizontal information) means the popularity of information sharing, which specifically refers to the company and population coverage of credit bureau. The depth indicator (vertical information) means the scope of information for borrowers that the credit bureau can collect and report. Specifically, the more details that the credit report contains, the less information asymmetry between the individual borrower and the bank.

Furthermore, empirical studies focused on the macro level (Jappelli \& Pagano, 2001; Nana, 2014; Djankov et al., 2007) mainly use the cross-sectional data of the major countries in the world. It should deserve the attention that this research method ignores some immeasurable factors such as culture, institution, and law which are critical to credit market. In our research, we choose countries of EU which have high integrations in several respects and use the panel data method for our empirical analysis.

\section{Theory}

\section{Information Sharing and Credit Access}

Stiglitz and Weiss (1981) pointed out that information asymmetry in the credit market leads to adverse selection, under which lenders cannot discriminate the good borrowers. Therefore, credit rationing would be an optimal choice. Information sharing enables the bank to ex ante differentiate the risk of borrowers while making consequent loan terms. In this way, adverse selection and credit rationing have been resolved (Pagano \& Jappelli, 1993). In addition, under information asymmetry, banks will utilize their information advantage to get 
"information rents" once the lending relationship is established. This leads to the "hold-up" problem (borrowers will be charged high interest rate, which reduces their effort to perform and increases the default) as well as moral hazard. Information exchange among banks would eliminate this kind of "information rents", thereby reducing moral hazard (Padilla \& Pagano, 1997). Even though the "information rents" no longer exist, information sharing among banks can also exert a kind of discipline effect, which means that the failure of payment would induce the exclusion of credit market. Thus, the moral hazard has been lowered (Padilla \& Pagano, 2000).

With regard to the institutional arrangement of information sharing system, broadening the width of information sharing will enable the previously unknown borrowers (low income or small business) to be recognized by the bank, which reduces the overall information asymmetry and improves the total credit availability. As stated by Miller (2003), good payment records and retailing business data can help borrowers to establish sound "reputational collateral", which is crucial for the small business or low income applications whose "real asset collateral" is scarce. Improvements in the depth of information sharing, on the other hand, will leave the risk characteristic of individual borrower much more precise for the bank. Chandler and Johnson (1992) and Chandler and Parker (1989) stressed that the accuracy of credit report which collects positive information and retailing data would be higher than that containing negative information only. So the credit access on the macro level could be improved via the ameliorations in the two aspects (width and depth) of information sharing system.

\section{Information Sharing and Credit Default Risk}

In this section, we utilize the model originally developed by Dell'Ariccia and Marquez (2006) to illustrate that in the high level of information sharing system, further improvements in width and depth of information sharing will expand credit while producing the negative "composition effects". Dell'Ariccia and Marquez (2006) mainly used this model to demonstrate how the bank allocates loan resources under information asymmetry. Thus, it is appropriate for us to add parameters of information sharing into the model.

Model description. Supposing that there exist a set of $1+\lambda$ enterprises in the economy, each enterprise has a project to invest, which requires $\$ 1$ initial capital. All the enterprises can be classified as good or bad with respective success rate of $\theta_{g}$ and $\theta_{b}\left(\theta_{g}>\theta_{b}\right)$. The corresponding return for success is $\bar{y}=y>0$ while $\bar{y}=0$ if failure. The model assumes that a good enterprise is more creditworthy than a bad one, which can be described as $\theta_{g} y>d, \theta_{b} y<d$ ( $d$ is the fund cost for the bank). The banking system in the credit market faces two kinds of borrowers: a mass of 1 known borrowers whose type (good or bad) is known by the bank and a mass of $\lambda(\lambda \in[0, \infty])$ borrowers whose type (good or bad) is not learned by the bank. Another assumption is that the distribution of good and bad borrowers in both known and unknown groups is the same with a proportion of $\alpha$ for good type and 1- $\alpha$ for bad one. The credit market has $N$ banks, each bank has learned $1 / N$ borrowers' type in the known group (a mass of 1), and shares acquired by each bank are not overlapping. All the banks have no information about borrowers in unknown group (a mass of $\lambda$ ).

There exists a three-stage game. In the first stage, all banks compete for unknown borrowers. The unknown borrowers faced by a single bank $i$ contain $\frac{N-1}{N}$ borrowers who have been known by its competitors ( $N-1$ banks), and $\lambda$ borrowers unknown to all the banks. Bank $i$ can offer loan contract $\left[\left(R^{k}, C^{k}\right)\right.$, $k=g, b]$ to all the borrowers. $R$ represents that the return bank can obtain if the project invested by the borrower is successful while $C$ represents the value of collateral that banks get in case of failure. In the second stage, bank $i$ determines the loan contract provided to its $1 / N$ known borrowers after realizing its competitors' strategy. 
In the third stage, bank $i$ decides to whether accept the loan application for both its known borrowers and unknown borrowers. As bank $i$ has no knowledge about the type of its unknown borrowers, it can only decide to whether offer the application based on the expected total return. Additionally, when more than one bank offers the same contract, borrowers will randomly choose the bank.

Now we extend the model by adding variables of information sharing. Assuming that banks exchange negative credit information for the proportion of $\beta$ in their known borrowers group (a mass of 1). Practically, this information sharing mechanism could be achieved through the minimum loan report requirement ${ }^{2}$, which means the threshold above which data on loans must be reported by banks.

Model equilibrium. The three-stage game has two Pure Strategy Nash Equilibrium equilibriums: a separating equilibrium and a pooling equilibrium ${ }^{3}$. In the separating equilibrium, bank $i$ will offer its known good borrowers the contract $\left(R_{g}^{1}, 0\right)$ while refusing its known bad borrowers. For the unknown borrowers, bank $i$ will offer the contract $\left(R_{s}, C_{s}\right)$ which can only be accepted by the good known borrowers and rejected by bad unknown borrowers because of no profit. In the pooling equilibrium, bank $i$ provides its known good borrowers and all the unknown borrowers (both good and bad) the contract $\left(R_{g}^{2}, 0\right)$, only its bad known borrowers cannot get the credit. It can be clearly seen that in the pooling equilibrium, banks decrease the lending standards and bad unknown borrowers can access the loan. This will lead to the increase in aggregate credit along with the deterioration of the loan portfolio.

Basically, whether the separating equilibrium or the pooling equilibrium is present is determined by the overall information asymmetry between banks and borrowers. To be specific, when the proportion of bad borrowers in all the unknown borrowers faced by bank $i$ is below a certain level, $\mathcal{L}<\mathcal{L}^{*}$, there exists a pooling equilibrium. Otherwise, if $\mathcal{L}>\mathcal{L}^{*}$, the separating equilibrium is present ${ }^{4}$. We express $\mathcal{L}$ as:

$$
\mathcal{L}=\frac{\left(\frac{N-1}{N}\right)(1-\alpha)\left(1-\beta+\beta \theta_{b}\right)+(1-\alpha) \lambda}{\lambda+\left(\frac{N-1}{N}\right)(1-\alpha)\left(1-\beta+\beta \theta_{b}\right)}=1-\frac{\alpha \lambda}{\lambda+\left(\frac{N-1}{N}\right)(1-\alpha)\left(1-\beta+\beta \theta_{b}\right)}
$$

In the first stage, bank $i$ clearly knows that their competitors ( $N-1$ banks) cannot abandon their known good borrowers, only leaving the bad one they know $\left(\left(\frac{N-1}{N}\right)(1-\alpha)\right)$ to bank $i$. Therefore, total unknown borrowers confronted by bank $i$ are $\left(\frac{N-1}{N}\right)(1-\alpha)+\lambda$. Now suppose that banks exchange negative credit information for $\beta$ of their known borrowers, $\left(\frac{N-1}{N}\right)(1-\alpha) \beta\left(1-\theta_{b}\right)$ previously unknown bad borrowers (but known by its competitors) have been learned by bank $i$ as they have negative credit record. In this case, the unknown group faced by bank $i$ consists of three parts: (1) $\lambda$ borrowers who are unknown to all banks; (2) $\left(\frac{N-1}{N}\right)(1-\alpha)(1-\beta)$ bad borrowers whose information is not shared but known by its competitors; and

\footnotetext{
${ }^{2}$ The law of one country determines that borrowers whose credit is above the minimum amount must be reported to the credit bureau. The lower the threshold, the more borrowers' information will be reported (shared). Many countries set the threshold at 0 , such as America and the United Kingdom.

3 For the specific proof process, please see Dell'Ariccia and Marquez (2006).

${ }^{4}$ For the specific proof process, please see Dell'Ariccia and Marquez (2006).
} 
(3) $\left(\frac{N-1}{N}\right)(1-\alpha)\left(\beta \theta_{b}\right)$ bad borrowers whose information has been exchanged without negative record. Thus, Equation (1) just shows the fraction of bad borrowers in the unknown group faced by bank $i$.

Equation (1) shows that $\beta$ is the decreasing function of $\mathcal{L}(\beta)$. As $\mathcal{L}(\beta)$ is constant and $\mathcal{L}(1)<\mathcal{L}^{*}<L(0)$, there exists $\beta^{*}$ that if $\beta>\beta^{*}, \mathcal{L}(\beta)<\mathcal{L}^{*}$; if $\beta<\beta^{*}, \mathcal{L}(\beta)>\mathcal{L}^{*}$. This model reflects that when the fraction $(\beta)$ of borrowers whose information exchanged is increasing (width of information sharing), there will be revealed a transition from separating equilibrium to pooling equilibrium, in which the amount of both loan and the default risk is rising.

Assuming that banks exchange information from "negative only" to "both positive and negative", the bank $i$ exactly knows the type of borrowers whose information is shared, of which the amount is $\left(\frac{N-1}{N}\right)(1-\alpha) \beta$. The expression of $\mathcal{L}$ can be rewritten as:

$$
\mathcal{L}_{1}=1-\frac{\alpha \lambda}{\lambda+\left(\frac{N-1}{N}\right)(1-\alpha)(1-\beta)}
$$

When $\beta$ is fixed and other things equal, we know that $\mathcal{L}_{1}(\beta)<\mathcal{L}(\beta)$. Thus, there exists $\beta=\tilde{\beta}$, satisfying $\mathcal{L}_{1}(\tilde{\beta})<\mathcal{L}^{*}<L(\tilde{\beta})$. Equation (2) shows that when the proportion of borrowers whose information exchanged reaches a certain level (width of information sharing), a change from "only negative information" shared to "both negative and positive information" shared (an increase in depth) will turn the equilibrium from "separating" to "pooling". This will induce the increase in credit access and risk, either.

Economic significance of the model. The model shows that the decrease in information asymmetry arising from information sharing development will influence the allocation of loan resource. Driven by the maximum of profit, banks are prone to the supply of loan for the high risk borrowers, especially when the overall information asymmetry confronted by banks is low. Specifically, when the width of information sharing reaches a high level, the fraction of high risk borrowers in all applicants will decline to a relative small part. Banks will change their loan strategy and provide credit to high risk borrowers, which lowers the quality of their portfolios and produces negative "composition effects". Moreover, improvements in the depth of information sharing will further reduce information asymmetry, thus inducing negative "composition effects" in the same way.

\section{Research Hypothesis}

Firstly, improvements in the width of information sharing will enable banks to learn more information about previously unknown borrowers, broadening the group of those who can access credit. Secondly, as it has been mentioned above, further increase in the width of information sharing at high level will impel the bank to loosen loan standards, leading to greater access to credit for riskier borrowers. Based on these arguments, we develop the following hypothesis:

H1: The width of information sharing is positively correlated with aggregate credit access.

The rise in the depth of information sharing, on the other hand, enhances the banks' knowledge of the borrowers' characteristics and fulfills more accurate prediction of credit report. Additionally, the increase in depth also gives rise to the credit expansion by reducing the overall information asymmetry confronted by the bank. These arguments lead to our second hypothesis as follows:

$\mathrm{H} 2$ : The depth of information sharing is positively correlated with aggregate credit access. 
In the credit market, some borrowers whose risk is particularly high never have a relationship with bank. Therefore, their data cannot be collected by the credit bureau. When the information sharing system develops, those who have the adequate risk characteristics for the loan have all been reported by the credit bureau. If continuing expanding the scope of information sharing, the remaining higher risk borrowers' information will be acquired by the bank. As implied by our model, this will result in the conversion of credit allocation that the high risk borrowers (bad type) can obtain credit since the information asymmetry in loan market faced by a single bank has lowered. Additionally, Brown et al. (2009) and Jappelli and Pagano (2005) also stated that those high risk borrowers will get the credit at higher interest rate rather than being refused by the bank. Based on this, we come up with the following hypothesis:

H3: When information sharing system develops into a certain level, expanding the width of information sharing will lead to the increase in aggregate default risk.

As aforementioned, improvements in the depth of the information sharing system, particularly when the width stays high, will compel the bank to loosen lending standards and induce easier access of loan for high risk borrowers. Besides, views from Vercammen (1995) and Padilla and Pagano (2000) show that long-term positive credit record leaves an occasional default insignificant, as these "good" borrowers can still obtain credit from other banks. Thus, excessive positive information could reduce the "discipline effects" and increase the probability of default. Along this line of reasoning, we raise our last hypothesis:

H4: When information sharing system develops into a certain level, improving the depth of information sharing will lead to the increase in aggregate default risk.

\section{Research Design}

This section conducts an empirical analysis to test the above four hypotheses. We will first describe our sample and variables and then briefly explain our regression specifications and provide summary statistics.

\section{Sample}

Since the year 2004, most EU countries have shown the trend of comprehensive information sharing development, leaving us a good sample to justify our assumptions. We gather data about information sharing and credit market development of EU countries from the year 2004 to 2014 and use the Panel Data method for analysis. For the 28 countries of EU, we exclude Luxembourg which does not have information sharing system as well as Cyprus and Malta whose data are missing. In sum, we get 271 observations for 25 countries. All the data in this paper are from the Doing Business Project and the World Development Indicator of the World Bank. ${ }^{5}$

Some transition countries of Eastern Europe and the former Soviet Union in EU members have not finished their market economy reform. The scale of their credit markets is considerably smaller compared to their counterparts in EU. Additionally, obvious divergences in economic development are revealed among EU members with the rapid expansion of EU in recent years. Djankov et al. (2007) and Nana (2014) documented that the influences that information sharing produced on credit markets of developing countries remarkably differ from that in developed countries. Therefore, we further divide our sample into two subsamples based on whether the EU member belongs to an OECD country. We have 20 countries of 220 observations for OECD group and five countries of 51 observations for non-OECD group. There are two reasons supporting our

\footnotetext{
5 Sources: World Bank: World Development Indicators Database; Doing Business Project, retrieved from http://www.doingbusiness.org/. Doing Business is a series of annual reports presenting the quantitative indicators on business regulation and the protection of property rights that can be compared across 189 economics.
} 
distinctions: (1) OECD is also known as club of developed and rich states of which members possess high level of economic development; and (2) OECD calls for rigid political, institutional, law, and especially market economic requirements for its members.

\section{Variables and Definitions}

Dependent variables: Credit access and credit default risk. It is well-known that the measure of credit access on macro level remains difficult. To solve this problem, Giannetti and Jentzsch (2013), Djankov et al. (2007), and Nana (2014) used "banks credit to private sector as a percentage of GDP" to measure the aggregate credit access. Although this is an indicator of financial depth development, reports from the World Bank in 2012 (Demirgüç-Kunt, Feyen, \& Levine, 2012) show that there is a significantly positive relation between this indicator and the credit access of one country. In this paper, we use the "banks credit to private sector/GDP" as the proxy for credit access.

As for the measure of credit default risk, Büyükkarabacak and Valev (2012) pointed out that the increase in credit default risk is highly associated with the increase in the proportion of non-performing loans. Jappeli and Pangano (2002) also agreed that the percentage of non-performing loans to gross loans is an adequate indicator to evaluate one country's credit default risk, but they argued that this indicator is not comparable among different countries as there is no uniform standard to confirm non-performing loans. The revised World Development Indicators database of the World Bank, however, has standardized its rule for non-performing loans in different countries, and the banking supervision rules among EU members are rather consistent. Therefore, it is appropriate for us to adopt the "bank non-performing loans/total gross loans" as the proxy to evaluate credit default risk.

Independent variables: Information sharing variable and control variables. Previous literatures by Jappelli and Pagano (2002), Nana (2014), Djankov et al. (2007), and Giannetti and Jentzsch (2013) only use the horizontal indicator or the vertical indicator as the proxy for information sharing. In this paper, we creatively divide the information sharing intro two aspects: the width and the depth of information sharing. We use the "adult population coverage of credit bureau" provided by the World Bank's "Doing Business Project" database as the proxy for the width of information sharing. Here comes an important question that the database offers the adult population coverage of both public credit registry and private credit bureau. According to Jappelli and Pagano (2002), Djankov et al. (2007), and Nana (2014), there exists a "substitute pattern" between public credit registry and private credit bureau, therefore, we use either of the two indicators of which the value is larger as the proxy variable. For the measure of the depth of information sharing, we use the "depth of credit information index" as the proxy. This index, which ranges from 0 to 6 , appraises the scope, availability, and the quality of the credit report. The larger the index, the more specific information that a credit reporting agency can provide.

Based on the research method by Djankov et al. (2007) and Nana (2014), we choose the GDP growth rate, inflation rate, and the legal right index as the control variables. GDP growth rate and inflation rate are used to measure the impact of various macroeconomic factors (such as fiscal and monetary policy) on credit access and credit default risk. Due to the concern of endogeneity, we do not choose interest rate as the control variable. Additionally, studies by La Porta, Lopez-de-Silanes, Shleifer, and Vishny (1998) and Jappeli and Pagano (2002) all clearly show that stronger creditor right protections are significantly associated with larger credit market and lower credit risk. In this way, we add the legal right index provided by the Doing Business Project as our control variable. This index is used to measure the degree to which the collateral and bankruptcy laws protect the rights of both borrowers and lenders. 
Table 1

Description of Variables

\begin{tabular}{|c|c|c|}
\hline Variable & Symbol & Definition \\
\hline $\begin{array}{l}\text { Banks credit to private } \\
\text { sector/GDP }\end{array}$ & Credit/GDP & $\begin{array}{l}\text { Financial resources provided to the private sector by other depository corporations } \\
\text { (deposit taking corporations except central banks). }\end{array}$ \\
\hline $\begin{array}{l}\text { Bank non-performing } \\
\text { loans/total gross loans }(\%)\end{array}$ & NPL/Loan & $\begin{array}{l}\text { The value of non-performing loans divided by the total value of the loan portfolio } \\
\text { (including non-performing loans before the deduction of specific loan-loss provisions). }\end{array}$ \\
\hline $\begin{array}{l}\text { Depth of credit } \\
\text { information index (from } \\
0=\text { low to } 6=\text { high) }\end{array}$ & CIN & $\begin{array}{l}\text { Rules affect the scope, accessibility, and quality of credit information available } \\
\text { through public or private credit registries. The index ranges from } 0 \text { to } 6 \text {, with higher } \\
\text { values indicating the availability of more credit information, from either a public } \\
\text { registry or a private bureau, to facilitate lending decisions. } \\
\text { The index contains the following six aspects: } \\
\text { (1) Are data on both firms and individuals distributed? } \\
\text { (2) Are both positive and negative credit data distributed? } \\
\text { (3) Are data from retailers or utility companies - in addition to data from banks and } \\
\text { financial institutions - distributed? } \\
\text { (4) Are at least two years of historical data distributed? } \\
\text { (5) Are data on loan amounts below } 1 \% \text { of income per capita distributed? } \\
\text { (6) By law, do borrowers have the right to access their data in the credit bureau or } \\
\text { credit registry? }\end{array}$ \\
\hline $\begin{array}{l}\text { Population coverage of } \\
\text { credit bureau }(\%)\end{array}$ & $\mathrm{COV}$ & $\begin{array}{l}\text { The number of individuals or firms listed by a private credit bureau or a public credit } \\
\text { register with current information on repayment history, unpaid debts, or credit } \\
\text { outstanding. The number is expressed as a percentage of the adult population. In this } \\
\text { paper, we use either of the public or the private coverage of which the value is larger. }\end{array}$ \\
\hline GDP growth (annual \%) & $G G D P$ & $\begin{array}{l}\text { Annual percentage growth rate of GDP at market prices based on constant local } \\
\text { currency. }\end{array}$ \\
\hline $\begin{array}{l}\begin{array}{l}\text { Inflation, GDP deflator } \\
\text { (annual \%) }\end{array} \\
\end{array}$ & Inflation & $\begin{array}{l}\text { Inflation as measured by the annual growth rate of the GDP implicit deflator shows } \\
\text { the rate of price change in the economy as a whole. }\end{array}$ \\
\hline Legal right index & $L I N$ & $\begin{array}{l}\text { It measures the degree to which collateral and bankruptcy laws protect the rights of } \\
\text { borrowers and lenders. The index ranges from } 0 \text { to } 10 \text {, with higher scores indicating } \\
\text { that these laws are better protected. }\end{array}$ \\
\hline
\end{tabular}

Note. Sources: World Bank: World Development Indicators Database; Doing Business Project (http://www.doingbusiness.org/).

\section{Model Specifications}

For the regression of our panel data, we include the country-fixed effects into our model. Considering that the length of the period is small in the sample (only seven years), especially compared to the number of the cross sections ( 25 countries), we exclude the time-fixed effects in our regression.

Firstly, we test H1: the relationship between the width of information sharing and the credit access. Combined with the method used by Jappelli and Pagano (2002), Nana (2014), and Djankov et al. (2007), we estimate the following panel regression Model (1):

$$
\frac{\text { Credit }}{G D P_{i t}}=\alpha+\beta_{1} C O V_{i t}+\beta_{2} G G D P_{i t}+\beta_{3} \text { Inflation }_{i t}+\beta_{4} L I N_{i t}+\mu_{i t}
$$

Based on $\mathrm{H} 1$, we expect the estimated coefficient, $\beta_{1}$ to be significantly positive, meaning that the expansion in the width of information sharing will increase the aggregate credit access.

Based on the regression Model (1), we further add the variable "depth of credit information index" into the regression to test the impacts of information sharing developments on credit market from the perspective of both width and depth of information sharing. The model could be estimated as follows:

$$
\frac{\text { Credit }}{G D P_{i t}}=\alpha+\beta_{1} C O V_{i t}+\beta_{2} C I N_{i t}+\beta_{3} G G D P_{i t}+\beta_{4} \text { Inflation }_{i t}+\beta_{5} L I N_{i t}+\mu_{i t}
$$


According to $\mathrm{H} 1$ and $\mathrm{H} 2$, both the signs of $\beta_{1}$ and $\beta_{2}$ should be significantly positive, implying that the improvements in both the width and depth of information sharing would promote the overall credit access.

To test $\mathrm{H} 3$ and $\mathrm{H} 4$, we use the percentage of bank non-performing loans to total gross loans as the proxy for credit default risk. We run the baseline regression of Model (3):

$$
\frac{N P L}{\text { Loan }_{i t}}=\alpha+\beta_{1} C O V_{i t}+\beta_{2} C_{i N_{i t}}+\beta_{3} G G D P_{i t}+\beta_{4} \text { Inflation }_{i t}+\beta_{5} \text { LIN }_{i t}+\mu_{i t}
$$

According to $\mathrm{H} 3$ and $\mathrm{H} 4$, size of the coefficients $\beta_{1}$ and $\beta_{2}$ should be significantly positive, indicating that the further increase in width and depth of information would induce the increase in credit default risk.

It should be noted that the depth of credit information index of which the changes mainly arise from the institutional reform, remains constant for most of the time. Besides, the number of cross sections in our panel data is small (25 countries for the full sample, 20 countries for OECD subsample, and five countries for non-OECD subsample). Adding the variable of depth of credit information index into the regression directly might produce technical biases. To deal with this, Galindo and Miller (2001) once used the Credit Bureau Index (similar with depth of credit information index in definition) to establish the interaction term with the internal cash flow in their study for the relationship between credit sharing and financial constraint. Technically, Wooldridge (2003) highlighted that although we cannot directly add the variables which remain constant with time into the fixed effect model, it is appropriate to build the interaction term by combining this variable with those that change with time. To further test $\mathrm{H} 3$ and $\mathrm{H} 4$, we introduce the intersection effect $\mathrm{COV}^{*} \mathrm{CIN}$ into regression and get Model (4):

$$
\frac{\text { Credit }}{G D P_{i t}}=\alpha+\beta_{1} C O V_{i t}+\beta_{2} C O V_{i t} * C I N_{i t}+\beta_{3} G G D P_{i t}+\beta_{4} \text { Inflation }_{i t}+\beta_{5} \operatorname{LIN}_{i t}+\mu_{i t}
$$

In this model, the predicted coefficients of $C O V$ and $C O V^{*} C I N$ should be positive and significant, which just corresponds with $\mathrm{H} 3$ and $\mathrm{H} 4$.

\section{Summary Statistics of the Main Variables}

Figures 2-5 show the mean of the major research variables' annual specific variations in the full sample and two subsamples. In the full sample, the mean of Credit/GDP was gradually increasing before 2009 and began to decline after that. The mean of NPL/Loan manifested an obvious decline before the year 2008 but then showed a substantial rise. There had been a steady increase in the mean of population coverage of credit bureau (COV) since 2004, which represents the trend of the whole population coverage. The depth of credit information index $(C I N)$ went through a slight rise during the 10 years, indicating that there also exist reforms in the depth of information sharing system. The variation in the mean of $C O V$ and $C I N$ implies that information sharing system in EU members has developed into the comprehensive stage, which leaves us a good sample to study the negative "composition effects".

It is of great interests to compare the difference between the OECD group and non-OECD group. The mean of annual Credit/GDP in OECD subsample is much larger than that in the non-OECD subsample. Conversely, the mean of annual NPL/Loan in OECD subsample is smaller. This difference means that the OECD countries in EU have more mature credit market than their non-OECD counterparts with greater credit access and lower credit default risk. In the figures reflecting information sharing development (Figures 4 and 5), 
non-OECD countries in EU have experienced a rapid process of information sharing development, which went through stages from the start-up to the comprehensive information sharing during the 11 years. This contrasts significantly with the OECD group, which has already established mature information sharing system in 2004. Therefore, it is critical for us to classify the full sample into two categories and study the differences of impacts produced by information sharing.

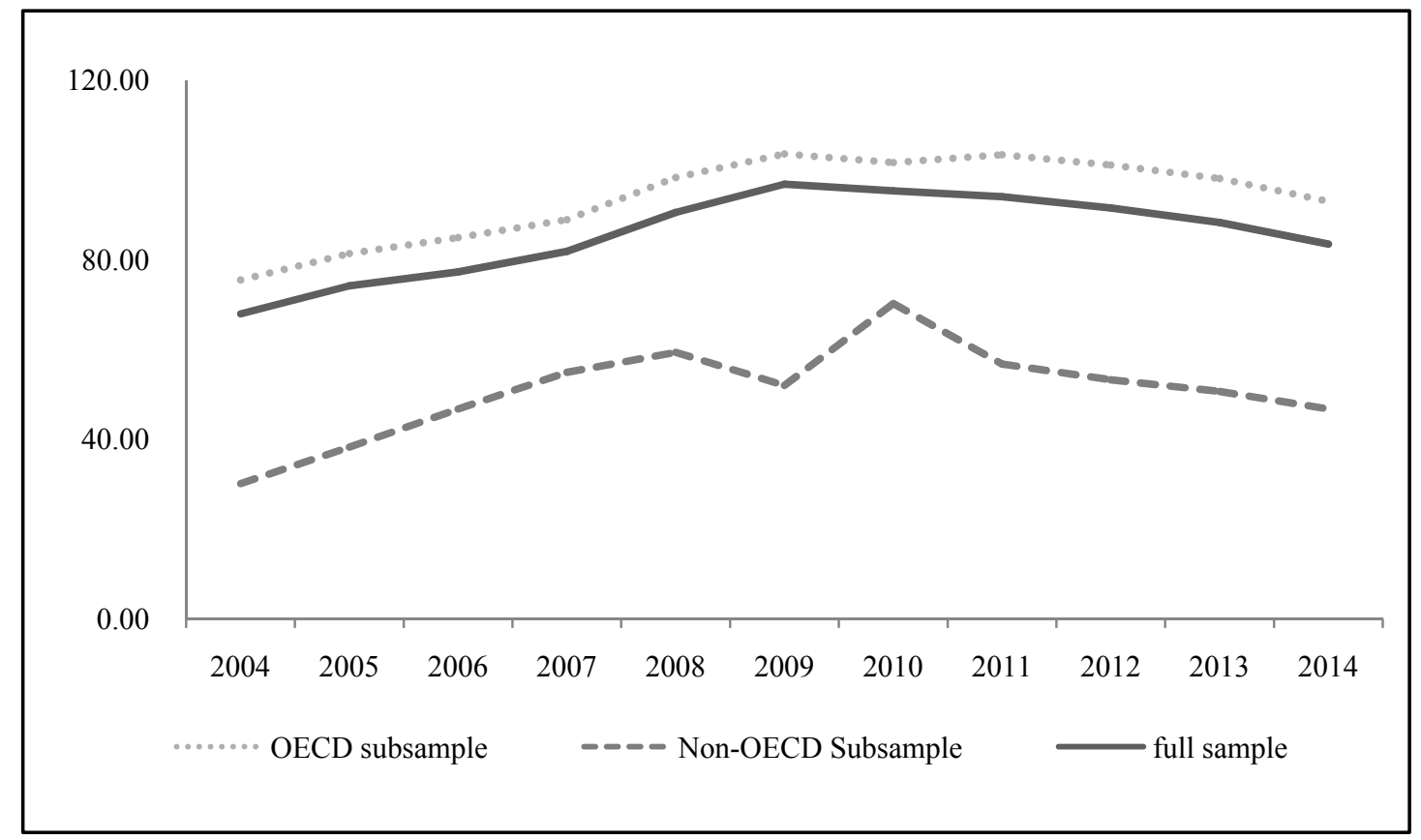

Figure 2. Mean of annual Credit/GDP (2004-2014).

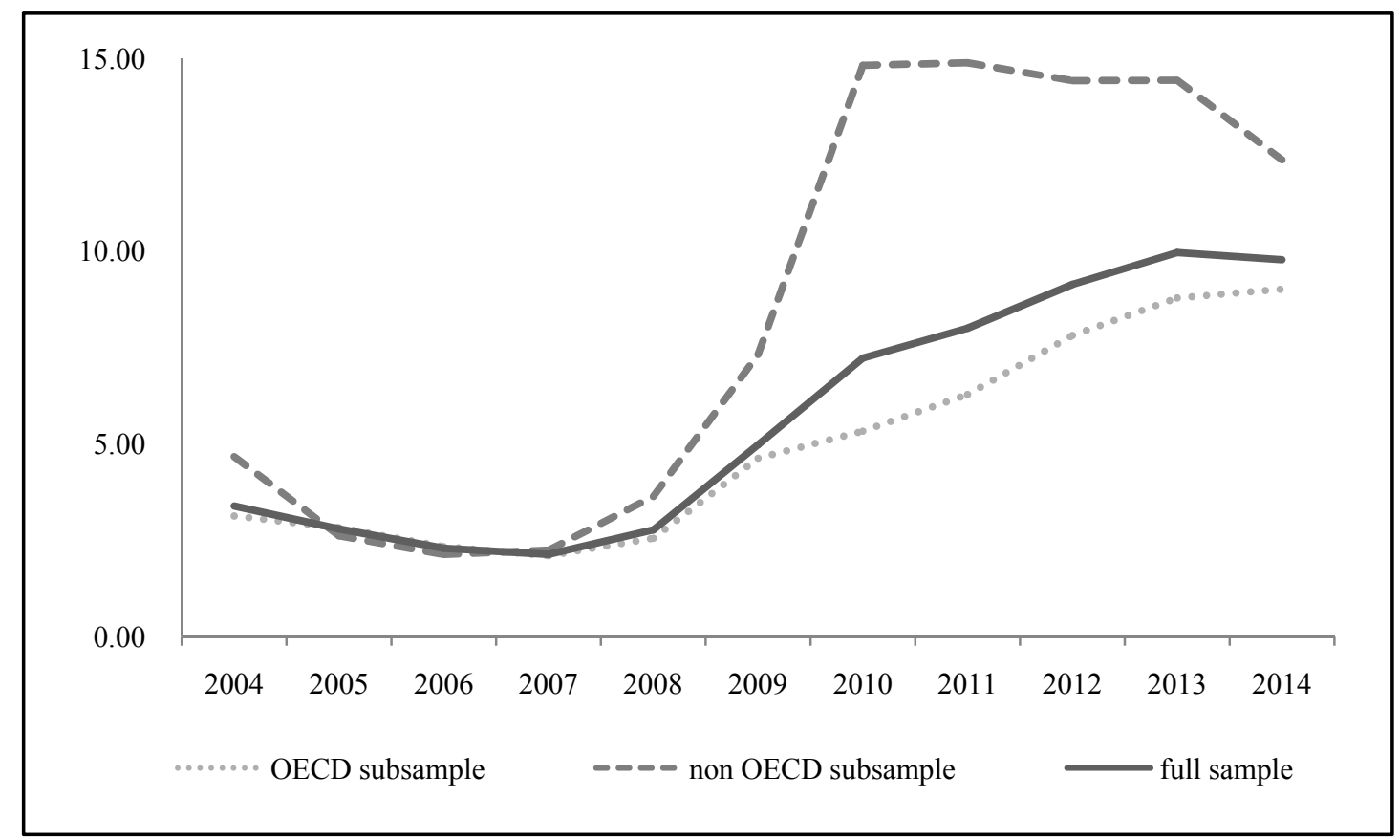

Figure 3. Mean of annual NPL/Loan (2004-2014). 


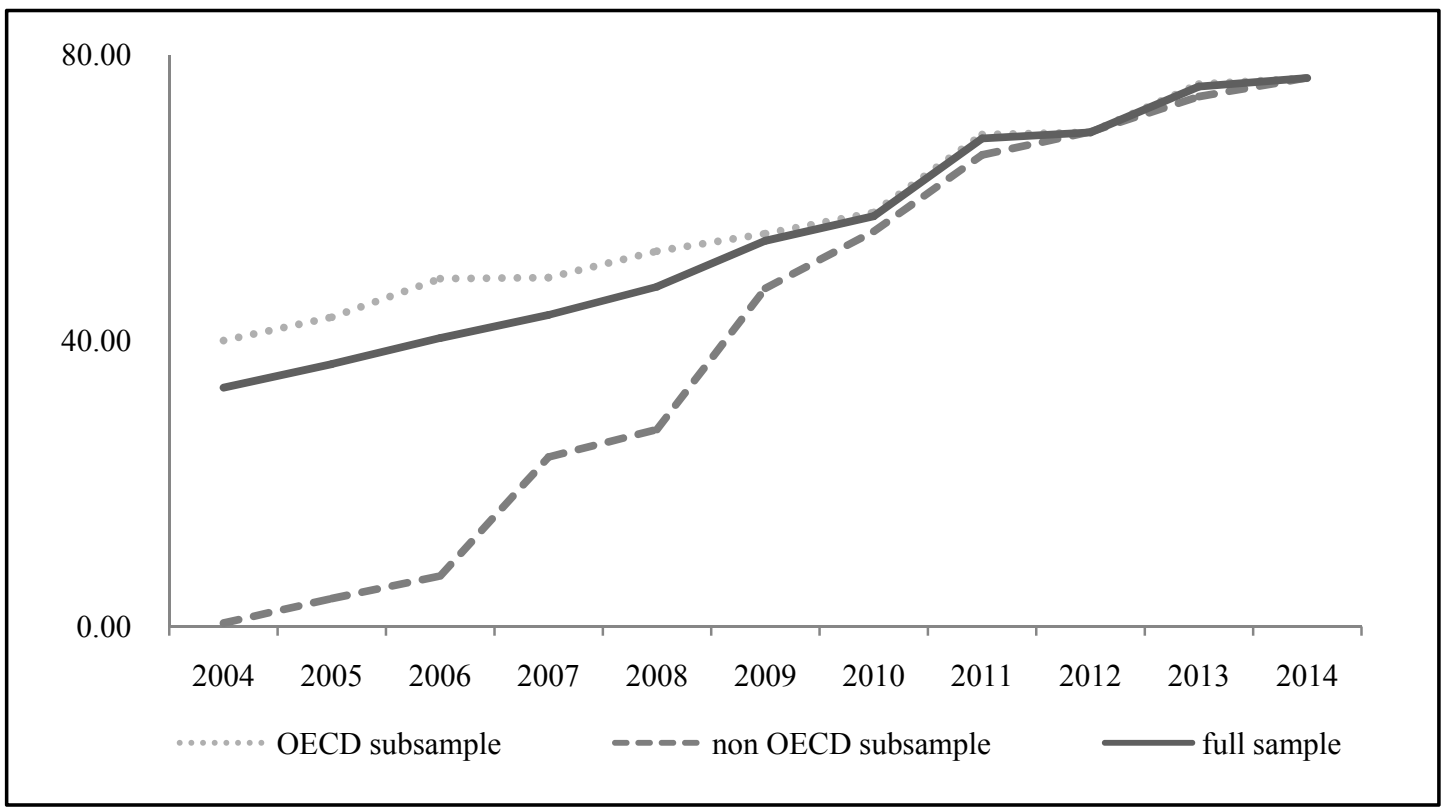

Figure 4. Mean of annual COV (2004-2014).

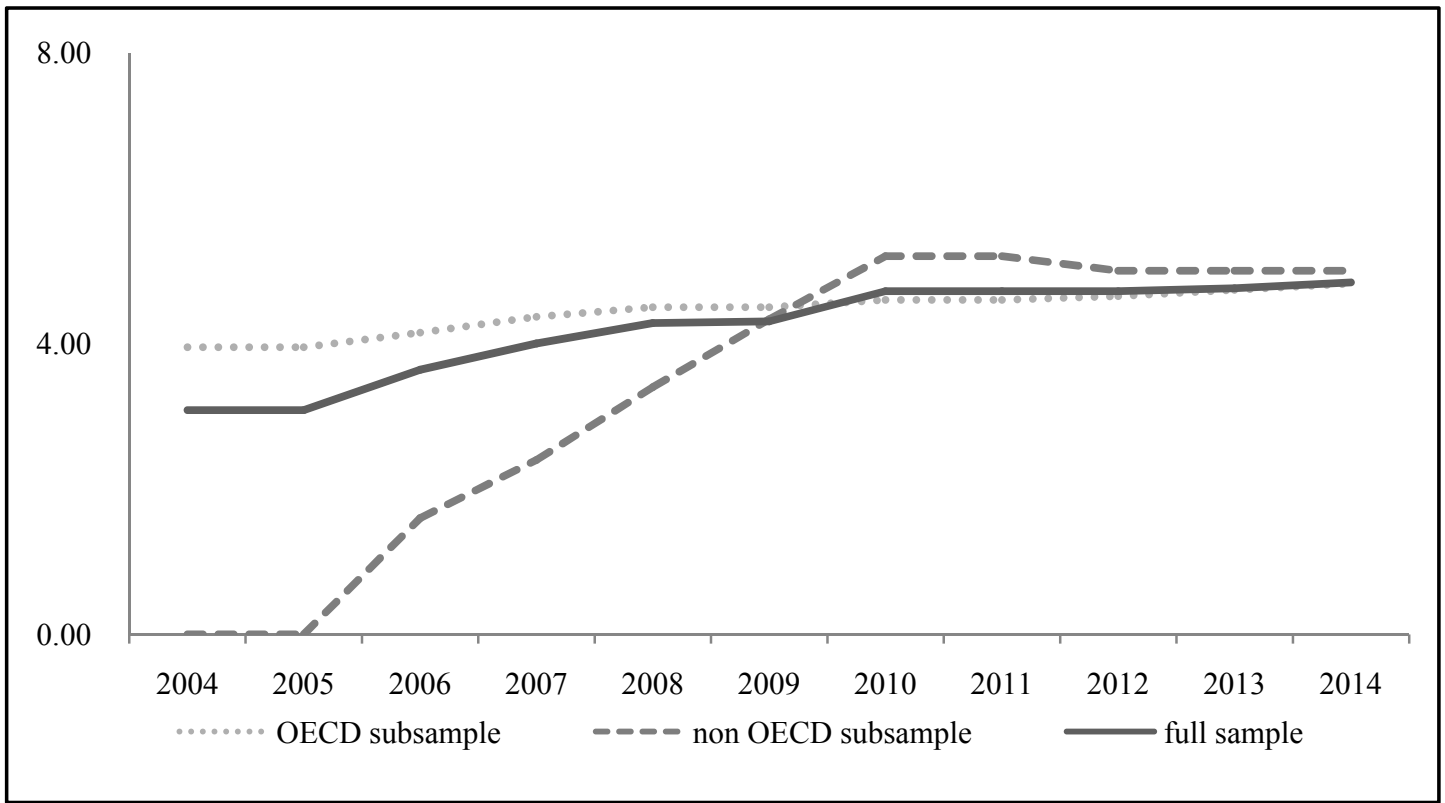

Figure 5. Mean of annual CIN (2004-2014).

\section{Empirical Results}

\section{Information Sharing and Credit Access}

Before we run the regression of the panel data, we firstly conduct the $F$-test and Hausman test to determine whether the fixed-effect model or the random-effect model should be employed. Table 2 reports the baseline results of estimated credit access using the regression Model (1) and Model (2). Columns (1)-(2) present the results for the regression in the full sample. Columns (3)-(4) present the results for the regression in the OECD subsample. And Columns (5)-(6) present the results for the regression in the non-OECD subsample. 
Table 2

Impacts of Information Sharing on Bank Credit/GDP

\begin{tabular}{|c|c|c|c|c|c|c|}
\hline \multirow{2}{*}{ Variable } & \multicolumn{2}{|c|}{ Full sample } & \multicolumn{2}{|c|}{ OECD subsample } & \multicolumn{2}{|c|}{ Non-OECD subsample } \\
\hline & (1) & (2) & (3) & (4) & (5) & (6) \\
\hline \multirow{2}{*}{ Constant } & $55.69^{* * *}$ & $46.944^{* * *}$ & $33.855^{*}$ & 20.461 & $49.723^{* *}$ & $46.089^{* *}$ \\
\hline & $(4.33)$ & $(5.116)$ & (19.118) & $(19.478)$ & $(23.324)$ & $(18.192)$ \\
\hline \multirow{2}{*}{$\mathrm{COV}$} & $0.172^{* * *}$ & $0.113^{* * *}$ & $0.255^{* * *}$ & $0.180^{* *}$ & $0.134^{*}$ & -0.026 \\
\hline & $(0.033)$ & $(0.031)$ & $(0.066)$ & $(0.072)$ & $(0.071)$ & $(0.063)$ \\
\hline \multirow{2}{*}{$C I N$} & & $3.041^{* * *}$ & & $3.893^{* *}$ & & $3.955^{* * *}$ \\
\hline & & $(0.428)$ & & $(1.626)$ & & $(0.799)$ \\
\hline \multirow{2}{*}{$G G D P$} & $-1.12^{* * *}$ & $-0.919^{* * *}$ & $-1.499^{* * *}$ & $-1.408^{* * *}$ & $-1.194^{* * *}$ & $-0.568^{*}$ \\
\hline & $(0.186)$ & $(0.176)$ & $(0.35)$ & $(0.348)$ & $(0.408)$ & $(0.347)$ \\
\hline \multirow{2}{*}{ Inflation } & 0.092 & 0.238 & $-1.464^{*}$ & $-1.487^{*}$ & 0.701 & 0.611 \\
\hline & $(0.329)$ & $(0.299)$ & $(0.826)$ & $(0.818)$ & $(0.489)$ & $(0.382)$ \\
\hline \multirow{2}{*}{$L I N$} & $3.25^{* * *}$ & $3.030^{* * *}$ & $7.573^{* * *}$ & $7.622^{* * *}$ & -0.476 & -1.079 \\
\hline & $(0.645)$ & $(0.745)$ & $(2.368)$ & $(2.321)$ & $(3.192)$ & $(2.481)$ \\
\hline
\end{tabular}

Notes. Columns (1), (3), and (5) present regression with only COV; Columns (2), (4), and (6) present regression with $\mathrm{COV}$ and $C I N .{ }^{* * *}$ indicates significance at $1 \%,{ }^{* *}$ indicates significance at $5 \%$, and ${ }^{*}$ indicates significance at $10 \%$. Standard errors are reported in parentheses.

In the specification of Columns (1) and (2), terms of population coverage of credit bureau (COV) yield a positive coefficient, which are both significant at $1 \%$. Specifically, the $1 \%$ increase in $C O V$ will lead to $0.17 \%$ and $0.11 \%$ increase in banks credit to private sector as a percentage of GDP in Models (1) and (2) respectively. This implies that improvements in the width of information sharing will promote credit access. Thus, H1 is justified. In Column (2), the coefficient on depth of credit information index (CIN) is positive and statistically significant. It has been estimated that 1 point increase in CIN is associated with $3 \%$ increase in banks credit to private sector as a percentage of GDP, indicating that improvements in depth of information sharing will substantially stimulate the credit access. Thus, $\mathrm{H} 2$ is justified.

Comparing the empirical results between OECD subsample and non-OECD subsample, we find that impacts on credit access produced by the information sharing differ in two groups. In the subsample of OECD countries, both coefficients on $\mathrm{COV}$ are positive and statistically significant, indicating that the width of information sharing matters a great deal in promoting credit availability. However, in the subgroup of non-OECD countries, the coefficient is only marginally significant in Model (1) and statistically insignificant in Model (2). This seems to imply that the width of information sharing does not function in increasing credit access for OECD countries. Overall, both size and statistical significance of the estimated coefficients on depth of credit information index $(C I N)$ are similar in the two subgroups, which are economically and statistically significant. This suggests that higher depth of information sharing is associated with larger private credit to GDP.

How to explain these results? Influenced by the planned economy factors, there still exists the credit rationing in the non-OECD countries' credit market. Thus, the scope of borrowers who can access credit is relatively fixed. Previously unknown borrowers whose information learned by the bank as a result of the increase in the width of information sharing might still be refused by the bank because of the credit rationing. The reform in depth of information sharing, on the other hand, will increase the total amount of credit that the existing borrowers will be granted. Accordingly, the increase in the depth of information sharing will produce identical effects in credit market of both OECD and non-OECD groups. 
Another point should be noted is that the strength of legal right index is highly positive with private credit to GDP with statistical significance at $1 \%$ level in both the full sample and OECD subsample. However, the size and statistical significance diminish in the non-OECD subsample. Our findings support conclusions from La Porta et al. (1997) and Djankov et al. (2007) that the effect of legal right is more important in richer countries.

\section{Information Sharing and Credit Default Risk}

As a first step, we also run the $F$-test and Hausman test to determine whether to establish fixed-effect model or random-effect model. Table 3 reports the baseline results of credit default risk using the regression Models (3) and (4). Columns (1)-(2) present the results for the regression in the full sample. Columns (3)-(4) present the results for the regression in the OECD subsample. And Columns (5)-(6) present the results for the regression in the non-OECD subsample.

Table 3

Impacts of Information Sharing on NPL/Loan

\begin{tabular}{|c|c|c|c|c|c|c|}
\hline \multirow{2}{*}{ Variable } & \multicolumn{2}{|c|}{ Full sample } & \multicolumn{2}{|c|}{ OECD subsample } & \multicolumn{2}{|c|}{ Non-OECD subsample } \\
\hline & (1) & (2) & (3) & (4) & (5) & (6) \\
\hline \multirow{2}{*}{ Constant } & $6.463^{* * *}$ & $7.913^{* * *}$ & $8.547^{* * *}$ & $6.012^{* * *}$ & $43.003^{* * *}$ & $40.374^{* * *}$ \\
\hline & (1.157) & $(1.015)$ & $(2.860)$ & (1.108) & $(9.484)$ & $(9.003)$ \\
\hline \multirow{2}{*}{$C O V$} & $0.067^{* * *}$ & $0.030^{* * *}$ & $0.068^{* * *}$ & $0.051^{* * *}$ & $0.101^{* * *}$ & 0.061 \\
\hline & $(0.006)$ & $(0.011)$ & $(0.015)$ & $(0.010)$ & $(0.033)$ & $(0.038)$ \\
\hline \multirow{2}{*}{$C I N$} & $0.385^{* * *}$ & & -0.185 & & $0.713^{*}$ & \\
\hline & $(0.094)$ & & $(0.352)$ & & $(0.386)$ & \\
\hline \multirow{2}{*}{$C O V^{*} C I N$} & & $0.009^{* * *}$ & & $0.006^{* * *}$ & & $0.014^{* *}$ \\
\hline & & $(0.002)$ & & $(0.002)$ & & $(0.005)$ \\
\hline \multirow{2}{*}{$G G D P$} & $-0.099^{* * *}$ & $-0.094^{* * *}$ & -0.122 & $-0.098^{* * *}$ & -0.112 & -0.18 \\
\hline & $(0.026)$ & $(0.024)$ & $(0.082)$ & $(0.030)$ & $(0.138)$ & $(0.123)$ \\
\hline \multirow{2}{*}{ Inflation } & $-0.565^{* * *}$ & $-0.513^{* * *}$ & $-0.848^{* * *}$ & $-0.536^{* * *}$ & $-0.593^{* * *}$ & $-0.534^{* * *}$ \\
\hline & $(0.063)$ & $(0.06)$ & $(0.189)$ & $(0.084)$ & $(0.179)$ & $(0.17)$ \\
\hline \multirow{2}{*}{$L I N$} & $-0.688^{* * *}$ & $-0.705^{* * *}$ & $-0.747^{* *}$ & $-0.685^{* * *}$ & $-4.646^{* * *}$ & $-4.144^{* * *}$ \\
\hline & $(0.153)$ & $(0.142)$ & $(0.352)$ & $(0.155)$ & $(1.286)$ & $(1.242)$ \\
\hline
\end{tabular}

Notes. Columns (1), (3), and (5) present regression with $C O V$ and $C I N$; Columns (2), (4), and (6) present regression with $C O V$ and $\mathrm{COV}^{*} \mathrm{CIN} ;{ }^{* * *}$ indicates significance at $1 \%,{ }^{* *}$ indicates significance at $5 \%$, and ${ }^{*}$ indicates significance at $10 \%$. Standard errors are reported in parentheses.

In the specification of Columns (1) and (2), both the coefficients on $\mathrm{COV}$ are positive and significantly different from zero at $1 \%$ level. The estimates indicated that the improvements in the width of information sharing indeed produce the negative "composition effects", which increase the proportion of non-performing loans. However, size of the $C O V$ coefficient is relatively small in both the models, implying the quantitatively weak effects in reality. Thus, H3 is justified. Turning to the depth of information sharing, the proxy variable depth of credit information index yields a positive and statistically significant (1\% level) coefficient in Column (1). The estimated coefficient of the interaction term $\mathrm{COV}^{*} C I N$ in Column (2) also displays the expected positive sign and is statistically significant at $1 \%$ level. The size of the coefficient is also economically meaningful, which suggests that when the population coverage of credit bureau is $50 \%(\mathrm{COV})$, one unit increase in $C I N$ will lead to the increase of share of non-performing loans by $0.45 \%$. This empirical 
result is consistent with our theoretical model prediction and our H4 that further advance in the depth of information sharing when the system develops into high level will exacerbate the aggregate default risk and induce the negative "composition effects".

The empirical results in the OECD subsample and non-OECD subsample suggest that sources of the negative "composition effects" arising from information sharing are different in those two groups. In specifications 3 and 4, COV coefficients are both statistically significant, but quantitatively small. This implies that the improvements in the width of information sharing just produce slightly negative "composition effects" for the OECD countries in EU. Coefficient on CIN in Column (3) is insignificant. In Column (4), despite the significance of the interaction term $C I N^{*} \mathrm{COV}$, the size of the coefficient is not economically meaningful. Thereby, it can be inferred that the increase in depth of information sharing will not influence the credit default risk of OECD countries. For the non-OECD countries, empirical results show that coefficients on $\mathrm{COV}, \mathrm{CIN}$ as well as the interaction term $\mathrm{COV}^{*} \mathrm{CIN}$ are constantly positive and significant, which implies that increase in both the width and depth of information sharing will bring the negative "composition effects" for non-OECD countries.

Additionally, the strength of legal right index $(L I N)$ shows the negative and statistically significant coefficients in all the three samples, indicating that enhancing the protections of creditors and borrowers right will substantially reduce the aggregate credit default risk. These strong promoting effects are also supported by conclusions from Jappelli and Pagano (2002).

\section{Conclusions}

This paper extends a three-stage game model established by Dell'Ariccia and Marquez (2006). Dell'Ariccia and Marquez (2006) presented a three-stage model to illustrate that one bank will lower its lending standard and expand credit when information asymmetry faced by it decreases. In our paper, we add the width and depth parameters to evaluate information sharing development in this model. Then, we utilize this model to examine the impacts on bank's lending behavior produced by the decrease in information asymmetry that arises from information sharing development. Our theoretical predictions show that when the width and depth of information sharing stay at high level, further improvements in those two indicators will turn the equilibrium of credit resources allocation from "separating" to "pooling", resulting in the increase of credit availability but the deterioration of credit portfolio.

Our empirical results from the data of EU countries, which are marching into comprehensive information sharing in recent years, clearly show the negative "composition effects" in credit market. It has been estimated that the $1 \%$ increase in the proxy "adult population coverage of credit bureau" will lead to the increase in private credit to GDP by $0.11 \%$ and proportion of non-performing loans by $0.06 \%$. In addition, one unit increase in the proxy "depth of information index" is associated with $3 \%$ increase in private credit to GDP and $0.4 \%$ increase in the proportion of non-performing loans. Those empirical results are supportive of the predictions of our mode.

We also compare the differences of impacts that information sharing exerts on the OECD and non-OECD EU members. Results indicate that sources of the negative "composition effects" just differ in those two groups: For OECD countries, these "composition effects" mainly result from the improvements in width of information sharing. In contrast, the loss of efficiency in non-OECD group of EU arises from both the width and depth reforms of information sharing, in which the effects of depth are stronger than the width. 
Our analysis sheds new light on the previous conclusions from Djankov et al. (2007) and Nana (2014) that information sharing stimulates the increase in the private credit to GDP. On another thing, this paper first examines the impacts that information sharing yields on the macro credit market of one country and argues that the comprehensive information sharing system which has been established in the US might bring about the loss of efficiency. In fact, the great loss resulted from the junk bond in year 2008 US financial distress just exemplifies this concern. The subordinated debt that was designed to the high risk borrowers cannot avoid the default at large scale even under the most comprehensive information sharing system.

Our research also provides insights on the information sharing system development of China with 1.3 billion population and more complicated economic relationships. The comprehensive information sharing system means the large costs and more importantly, the loss of credit efficiency.

Last but not least, we cast doubt on the predictive power and usefulness of credit report based on Big Data adopted by some Credit Bureaus such as Zest Finance. The Big Data technology can merely base on the segmented information such as social network data and payment history to describe the risk characteristic of borrowers. Does this mere positive information predictions function in credit reporting? We believe it deserves further investigations.

\section{References}

Behr, P., \& Sonnekalb, S. (2012). The effect of information sharing between lenders on access to credit, cost of credit, and loan performance - Evidence from a credit registry introduction. Journal of Banking \& Finance, 36(11), 3017-3032.

Brown, M., Jappelli, T., \& Pagano, M. (2009). Information sharing and credit: Firm-level evidence from transition countries. Journal of Financial Intermediation, 18(2), 151-172.

Büyükkarabacak, B., \& Valev, N. (2012). Credit information sharing and banking crises: An empirical investigation. Journal of Macroeconomics, 34(3), 788-800.

Chandler, G. G., \& Johnson, R. W. (1992). The benefit to consumers from generic scoring models based on credit reports. IMA Journal of Management Mathematics, 4(1), 61-72.

Chandler, G. G., \& Parker, L. E. (1989). Predictive value of credit bureau reports. Journal of Retail Banking, 11(4), 47-54.

Čihák, M., Demirgüç-Kunt, A., Feyen, E., \& Levine, R. (2012). Benchmarking financial systems around the world. Policy Research Working Paper.

Dell'Ariccia, G., \& Marquez, R. (2006). Lending booms and lending standards. The Journal of Finance, 61(5), 2511-2546.

Dierkes, M., Erner, C., Langer, T., \& Norden, L. (2013). Business credit information sharing and default risk of private firms. Journal of Banking \& Finance, 37(8), 2867-2878.

Djankov, S., McLiesh, C., \& Shleifer, A. (2007). Private credit in 129 countries. Journal of Financial Economics, 84(2), $299-329$.

Doblas-Madrid, A., \& Minetti, R. (2013). Sharing information in the credit market: Contract-level evidence from U.S. firms. Journal of Financial Economics, 109(1), 198-223.

Fosu, S. (2014). Credit information, consolidation and credit market performance: Bank-level evidence from developing countries. International Review of Financial Analysis, 32, 23-36.

Galindo, A., \& Miller, M. J. (2001). Can credit registries reduce credit constraints? Empirical evidence on the role of credit registries in firm investment decisions. Prepared for the Seminar "Towards Competitiveness: The Institutional Path", Annual Meetings of the Board of Governors, Inter-American Development Bank and Inter-American Investment Corporation, Santiago, Chile, March 16, 2001.

Giannetti, C., \& Jentzsch, N. (2013). Credit reporting, financial intermediation and identification systems: International evidence. Journal of International Money and Finance, 33, 60-80.

Houston, J. F., Lin, C., Lin, P., \& Ma, Y. (2010). Creditor rights, information sharing, and bank risk taking. Journal of Financial Economics, 96(3), 485-512.

Jappelli, T., \& Pagano, M. (2002). Information sharing, lending and defaults: Cross-country evidence. Journal of Banking \& Finance, 26(10), 2017-2045.

Jappelli, T., \& Pagano, M. (2005). Role and effects of credit information sharing. CSEF Working Papers No. 136. 
La Porta, R., Lopez-de-Silanes, F., Shleifer, A., \& Vishny, R. W. (1997). Legal determinants of external finance. The Journal of Finance, 52(3), 1131-1150.

Miller, M. J. (2003). Credit reporting systems and the international economy. Defusing Default Incentives \& Institutions, 1.

Nana, P. N. (2014). Legal rights, information sharing, and private credit: New cross-country evidence. The Quarterly Review of Economics and Finance, 54(3), 315-323.

Padilla A. J., \& Pagano, M. (2000). Sharing default information as a borrower discipline device. European Economic Review, 44(10), 1951-1980.

Padilla, A. J., \& Pagano, M. (1997). Endogenous communication among lenders and entrepreneurial incentives. Review of Financial Studies, 10(1), 205-236.

Pagano, M., \& Jappelli, T. (1993). Information sharing in credit markets. The Journal of Finance, 48(5), 1693-1718.

Stiglitz, J. E., \& Weiss, A. (1981). Credit rationing in markets with imperfect information. American Economic Review, 71(3), 393-410.

Vercammen, J. A. (1995). Credit bureau policy and sustainable reputation effects in credit markets. Economica, 62(248), 461-478.

Wooldridge, J. M. (2003). Introductory econometrics: A modern approach (2nd ed.). Mason, OH: South-Western College Publishing/Thomson Learning, 783. 